\title{
The Development of Social Competence in Preschoolers with Disabilities as the Condition for Their Successful Educational Integration
}

\author{
Elena Ermolaevna Dmitrieva*, Elena Yurievna Medvedeva, Elena Alexandrovna Olkhina, \\ Svetlana Evgenievna Uromova, Svetlana Nikolayevna Kashtanova
}

Nizhny Novgorod State Pedagogical University (Minin University), Nizhny Novgorod, Russia

Received April 8, 2020; Revised May 21, 2020; Accepted June 16, 2020

Copyright $\bigcirc 2020$ by authors, all rights reserved. Authors agree that this article remains permanently open access under the terms of the Creative Commons Attribution License 4.0 International License

\begin{abstract}
The article presents the results of a theoretical and experimental study of an age-related psychological formation - social competence in preschool children with disabilities. The characteristic of diagnostic tools aims at studying the cognitive, emotional and behavioral component of social competence is given. The article reveals the conceptual foundations and stages of experimental research. At the first stage of the study, the levels of social competence formation have been identified and described in accordance with the identified assessment criteria. The analysis of the influence of the level of development of social competence components on the process of social adaptation to new conditions in special (correctional) and inclusive educational organizations has been presented. The experimental data presented in the study indicate systemic lack of social competence in preschool children with disabilities of various nosological groups (children with mental retardation, children with mild mental retardation, children with general speech underdevelopment, and children with visual impairments). At the second stage of the study, it has been indicated that the pedagogically organized inclusion of children with disabilities into the system of new social relations (at the stage of adaptation to school) is a key condition for their successful socialization. The necessity of the activation of their developmental capabilities in a changing situation of social development has been substantiated. It is proved that the social competence of children with disabilities will be the subjective prerequisite of school adaptation.
\end{abstract}

Keywords Children with Disabilities, Social Competence, Social Intellect, Role Behavior, School Adaptation, Educational Integration, Inclusive Education

\section{Introduction}

A competency-based education model involves the formation of students' ability to solve problems in various areas of social life.

This approach assumes that students have social competence ensuring their successful socialization. In modern psychological and pedagogical science, various aspects and components of social competence are considered [1-3].

Issues of the structure, methods, and diagnostics of social competence, the ways and means of its formation at the stage of transition from one social development situation to another, are presented in sufficient detail in these studies $[4,5]$. A theoretical review of the literature and practical experience shows that the consideration of the problem of social competence is carried out only in relation to normatively developing children. At the same time, issues of social competence in children with disabilities do not become the subject of close attention [6-8].

The need for a detailed analysis of the process of formation of social competence in conditions of deviating development is dictated by the transition of the Russian education system from defectological to a sociocultural paradigm. Implementation of a system of special support for children with disabilities presents a vital trend in the modern development of education in Russia [9-11]. With the development of educational integration processes, the problem of social and psychological adaptation of children with disabilities and their inclusion in the system of social relations comes to the foreground. A child's personality and the actualization of its potential in the process of socialization are the primary guides for psychological and pedagogical interventions. The main goal of the psychological support for children with disabilities is the creation and implementation of a system of psychological 
interventions aimed at overcoming the difficulties in their socialization and integration into society [12-14]. The issues of social and personal development of children with disabilities significant for developing the problems of their socialization have important theoretical, methodological and applied value in the context of special and inclusive education [15-17].

The implementation of the tasks of optimal social and educational integration of children with disabilities discloses several scientific, organizational, and methodological problems relates to the patterns of socialization of these children at different age-related development levels. In this context, it is necessary to take into account the factors of socialization that determine the conditions for practical implementation of personality-oriented diagnostics and correctional and development-inducing programs. Preschool age of child bears special significance in this context, presenting the period of personal and social development at which the foundation of social ties and relations with society is laid and the psychological mechanisms of an adequate response to various social situations are formed [18-21].

\section{Research Objective}

The goal of the study is to explore the development of social competence as a new personality formation in preschool children with disabilities, as well as the formation of the psychological mechanisms of maladaptive processes in children with disabilities in an inclusive educational environment at the initial stage of school education related to the insufficient level of social competence (role behavior) development in preschool childhood.

The key objectives of the study are:

- To study the qualitative features of the formation of social competence in the complex of intellectual, emotional, and behavioral components in preschool children with disabilities;

- To identify the role of social competence development in the enhancement of adaptive capabilities in children with disabilities at the initial stage of studying in an inclusive educational environment;

- To trace the possibilities for the development of social competence in preschool children with disabilities in the conditions of purposeful pedagogical interventions.

The methodological basis of the study is defined in the context of L.S. Vygotsky's cultural-historical paradigm of child mental development. Its key ideas on the unity of the laws of development in ontogenesis and dysontogenesis include the dominating role of the sociocultural context in the development of a child's psyche (taking the biological factor into account) and the recognition of the unity of intellect and affect as a mechanism for the development of a child's personality [7, 11, 22].

The conceptual provisions of our study include the idea of personality as a system of person's relations to the surrounding reality, the most important of which are the relations to the objective world, other people, and the person themselves [1]. Social competence is understood as a point of intersection and transformation of various relations a child has, a new personality formation of the crisis of seven years. Social competence objectifies the components of the social self of a child and determines the degree of success in following the assigned social roles [23].

The article covers two research stages. The first stage includes a study of the specific features of social and personal development of preschool children with disabilities examined through the development of their social competence.

\section{Methods}

The first stage of the experimental study is aimed at studying social competence and its components (cognitive, emotional, and behavioral) in preschool children with disabilities. Theoretically substantiated methods, criteria, and level features of development of the defined components are used [6].

The second stage of the experimental study is aimed at defining the presence of correlation dependencies of the revealed features of social and personal development and indicators of the successful adaptation of these children to schooling.

For the identification of the level of development of the cognitive component of social competence (social intellect), a child is asked to evaluate moral and ethical conflicts (the Comprehension subscale from the Wechsler Intelligence Scale for Children (WISC)). The criteria for the assessment of the child's cognitive component included the knowledge of the norms of behavior and ways of carrying out joint activities, resolving conflict situations, and understanding the motives behind people's behavior, as well as the estimation of peers' and one's personality traits.

Following the age norms, we identify the following levels of development of the said component in preschool children with disabilities:

- High level: the child shows independence in assessing the situation, their evaluation is focused on social norms, they use value judgments and present a constructive solution;

- Average level: with the help of an adult the child searches for a solution to a problem situation, does not provide arguments for the desire to correlate the assessment of the situation with social norms, the undifferentiated assessments of the situation are dominating; 
- Low level: the child is passive in the assessment of the situation, agrees with the adult's arguments, proposes an unconstructive and unreasoned solution.

To determine the level of development of the emotional component of social competence, we used the "Rukavichki" method by G.A. Tsukerman and the "Mozaika" method by E.O. Smirnov. The assessment criteria included orientation on the partner's emotional state, their desires and interests, emotional identification with the state of a peer, and the ability to act prosocially in the interaction with a peer partner.

The levels of development of the emotional component in preschool children with disabilities are:

- High level: the child reacts emotionally to the partner's actions, strives for the coordination of actions, proactive social actions (actions in favor of the partner) are observed;

- Average level: the child strives for a conflict-free interaction with the partner, reacts emotionally to the particular actions of the partner, is capable of prosocial actions on the partner's demand;

- Low level: the child is immersed in their activity, evaluates the partner's actions negatively, is not capable of prosocial actions.

The experimentally created situation of a child exercising a delayed role task (the role of a person on duty) is used to evaluate the behavioral component of social competence. The assessment criteria includes the child's acceptance of the social task and the role behavior requirements and the degree of role self-regulation.

The levels of development of the behavioral component in preschool children with disabilities are:

- High level: the child can maintain the goal and the requirements for role behavior for the designated period;

- Average level: the child accepts the goal and requirements for role behavior but retains the original social task only for a short period;

- Low level: the child understands the social meaning behind the situation poorly and quickly loses the original goal and orientation on the required role behavior.

\section{Research Sample}

The experimental study covers 240 children with disabilities aged 6 to 8 years and studying in compensating groups of special (correctional) and inclusive educational organizations in Nizhny Novgorod, Russia. Of these, 60 children were with mental retardation, including 30 of them being observed at the school stage, 60 children were with level III of general speech underdevelopment, 60 children had mild mental retardation, and 60 children suffered from visual impairments.

\section{Results and Discussion}

The level characteristics of the development of the cognitive component of social competence in children with disabilities are presented in Figure 1.

The low level of development of the cognitive component, or social intellect, is observed in children with mild mental retardation and visual impairment (in 73.3\% and $53.3 \%$ of children, respectively). The children demonstrate poor ability to analyze and search for ways to resolve conflicts arising during interaction and communication. The children suggested unconstructive ways of problem resolution and easily agreed with the understanding of a situation suggested by an adult. The average level of development of the cognitive component of social competence dominated in children with mental retardation and general speech delay (in 56.7\% and 58.4\%, respectively). When discussing moral and ethical conflicts, the children sought a way out of problem situations with the help of leading questions, demonstrated a tendency to avoid making decisions, and experienced difficulties in understanding social norms governing relationships. The high level of development of the emotional intellect is not found in the studied groups of children. 


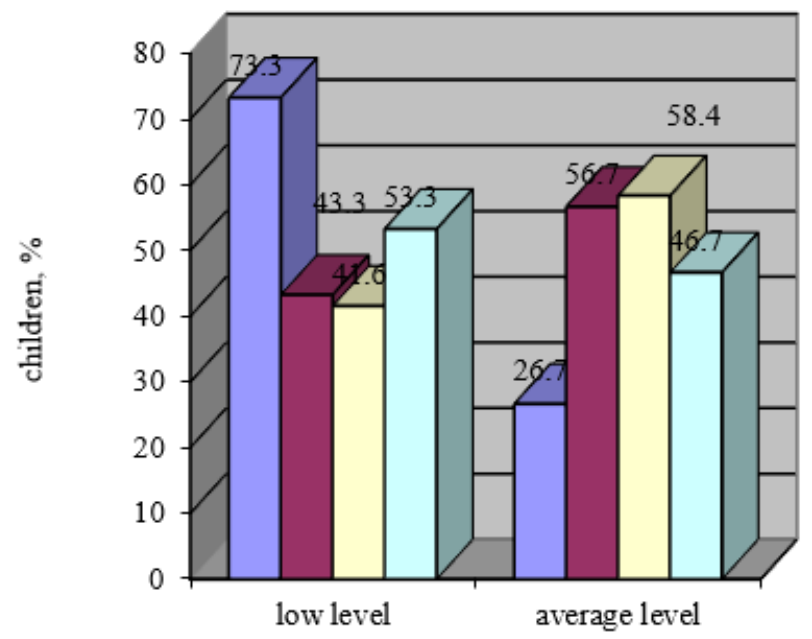

口Children with mild mental retardation

口Children with mental retardation

口Children with general speech delay

口Children with visual impairment

Figure 1. Levels of cognitive component development

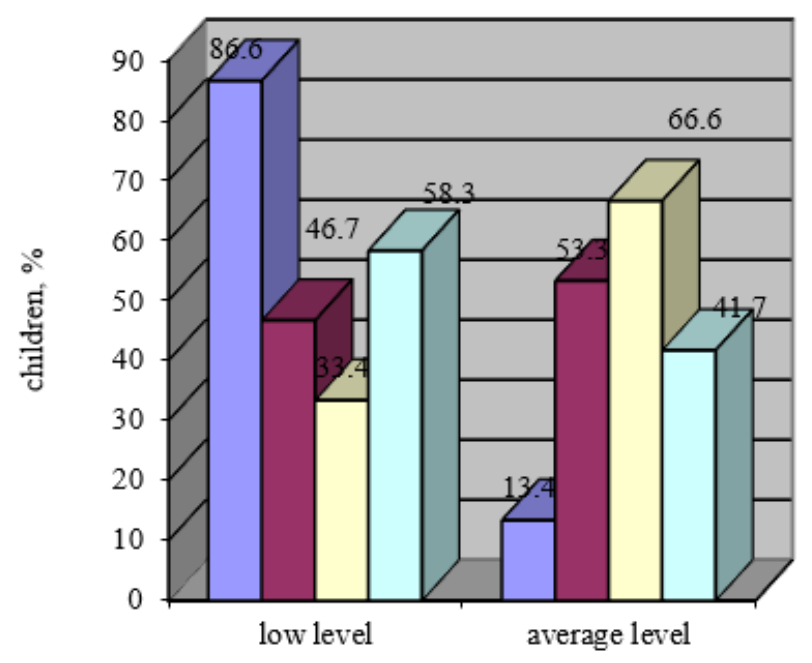

口Children with mild mental retardation

口Children with mental retardation

口Children with general speech delay

口Children with visual impairment

Figure 2. Levels of emotional intellect development

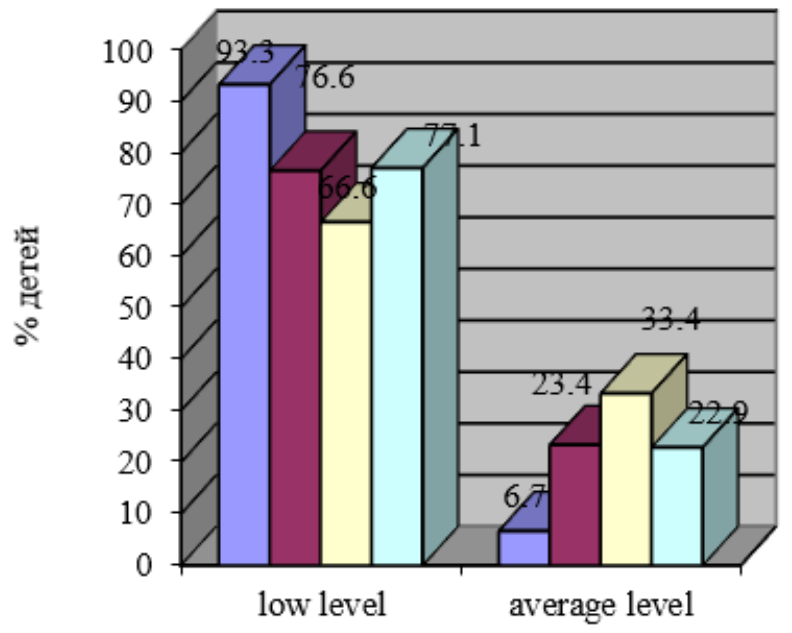

口Children with mild mental retardation

$\square$ Children with mental retardation

口Children with general speech delay

aChildren with visual impairment

Figure 3. Levels of behavioral component development 
The level characteristics of the development of the emotional component of social competence in children with disabilities are presented in Figure 2.

The low level of development of the emotional component of social competence is dominant in children with mild mental retardation and visual impairment (in $86.6 \%$ and $58.3 \%$, respectively). The behavioral patterns characteristic of the children on this level are the indifferent attitude towards the partner, emotional coldness, and avoidance of problem resolution in conflict situations. The desire to help peers is recorded in isolated cases. The average level of the emotional component is recorded in children with mental retardation and general speech delay despite the variability in their behavior (in 53.3\% and $66.6 \%$, respectively). The children with a dominance of this level of the emotional component development are emotionally involved in the partner's activity and demonstrate the ability to act prosocially at the partner's request. The high level of development of this component is not observed in the experiment sample.

The level characteristics of the development of the behavioral component of social competence in children with disabilities are presented in Figure 3.

The low level of the behavioral component of social competence (role behavior) dominates in all groups of children with disabilities participating in the experiment. The children understand the social meaning of the situation poorly and quickly lost the goal and requirements for role behavior. The children who demonstrate the average level of development of the behavioral component accepte the social task and demonstrated motivational readiness to fulfill the role requirements but maintained the orientation on the goal for a short period. The high level of development of the behavioral component in children with disabilities is not observed.

According to the results of the first stage of the experiment, the majority of preschool children with disabilities of various nosological groups even at the beginning of schooling dose not possess sufficient knowledge of the norms of behavior and ways of resolving conflict situations. They are unable to analyze their peers' actions and understand their moral component. The children with disabilities demonstrated situational interest in peers, the dominance of egocentric position in partner communication, and a lack of readiness for empathy and partnership. They also show a poor ability to accept and maintain a social task and role behavior requirements. These results are evidence of the insufficient development of a child's personal basis in relation to oneself and one's peers that involves a synthesis of intellectual and emotional processes.

The results of our study, therefore, indicate the deformation of the formation of self-image and its social component in preschool children with disabilities.

The second stage of our research involves the experimental study of the connection between the social and personal development of children with disabilities (the development of their social competence) and the indicators of school adaptation. With this goal, we examine 307 to 8-year-old children with disabilities studying in correctional groups of mass schools based on the indicators of school behavior indicating the characteristics of school adaptation.

To assess the characteristics of school adaptation, we examine the social sphere of children's activity, involving the specific characteristics of communication with the teacher (school behavior) and the ability to cooperate with a partner. The learning-related component of school life was also diagnosed in the aspects of mastery of program requirements and the structural (motivational, operational, and regulatory) components of the learning activity.

The specific characteristics of communication with the teacher and the degree of success in mastering program requirements were evaluated based on the expert assessments provided by the teachers of the educational institutions. The level of cooperation and the ability to plan one's actions and negotiate with a partner are assessed using the "Labirint" method (E.E. Kravtsova). The ability to master the structure of the educational activity is assessed using the method by U.V. Ulenkova. Qualitative level characteristics were used for the assessment of school adaptation characteristics [18].

The level characteristics of the school adaptation indicators are presented in Table 1.

At the second stage of the study, the indicators of school adaptation are compared with the level characteristics of social competence. According to the results of our study, children with a low level of social competence development demonstrated an inability to behave normatively, accept a learning task, and cooperate with peers.

Table 1. Levels of the school adaptation indicators development

\begin{tabular}{|c|c|c|c|}
\hline \multirow{2}{*}{ School adaptation indicators } & \multicolumn{3}{|c|}{ Levels of development } \\
\cline { 2 - 4 } & High & Average & Low \\
\hline School achievements & 6.6 & 40.0 & 53.4 \\
\hline Mastery over school activity & 6.6 & 43.3 & 50.1 \\
\hline Cooperation level & 3.3 & 46.6 & 50.1 \\
\hline School behavior & 3.3 & 43.3 & 53.4 \\
\hline
\end{tabular}

The establishment of correlations using the Spearman coefficient demonstrate that all indicators of school adaptation correlated significantly with the behavioral component of social competence (significance at the levels of 0.01 and 0.05 ). A significant correlation is also found between the level of mastery over the structure of educational activity and the development of the cognitive component of social competence. The nature of relationships with a peer in a situation of cooperation correlates significantly with the development of the emotional component of social competence. 


\section{Conclusions}

The results of the study allowed us to conclude with a certain degree of confidence that social and personal development of children, specifically the high level of development of the cognitive component of social competence (role behavior), is a factor determining the school adaptation of children with mental retardation in the integrative environment of an educational institution. In addition, the results of an experimental study of preschool children with disabilities of various nosological groups prove that the ability to realize their position in relationships with adults and peers and to organize their behavior activated their adaptive capabilities.

The results of our study indicate the social and personal immaturity of children with various developmental disabilities and highlight the problem of overcoming their social and personal immaturity and the implementation of correctional and development-inducing personality-oriented programs in preschool childhood.

\section{REFERENCES}

[1] M. I. Lisina. Obshchenie, lichnost i psikhika rebenka. [Communication, personality and psyche of a child], The Institute of Practical Psychology, Moscow, 1997.

[2] R. U. Arifulina, V. E. Nikishin, A. Y. Meshchenkova, L. A. Iugai, J. V. Shlykova. Identification of the degree of adaptation of children to the conditions of a preschool educational organization, Perspektivy Nauki i Obrazovania, Vol. 33, No. 3, 203-210, 2018.

[3] N. D. Bazarnova, Y. V. Afonina, O. V. Pravdina. Model of integration of the subjects of the educational space of the initial school, Perspektivy Nauki i Obrazovania, Vol. 33, No. 3, 198-202, 2018.

[4] C. L. Salisbury, M. M. Palombaro, W. M. Hollowood. On the nature and change of an inclusive elementary school, The Journal of the Association for Persons with Severe Handicaps, Vol. 18, 75-84, 1993.

[5] Z. V. Smirnova, E. A. Kuznetsova, M. I. Koldina, S. V. Dyudyakova, A. B. Smirnov. Organization of an Inclusive Educational Environment in a Professional Educational Institution, Lecture Notes in Networks and Systems, Vol. 73, 1065-1072, 2020.

[6] E. E. Dmitrieva, O. N. Dvurechenskaia. Psikhologicheskie osobennosti sotsializatsii detei doshko'nogo i mladshego shkolnogo vozrasta s ogranichennymi vozmozhnostiami zdorovia: monografiia [Psychological characteristics of socialization in preschool and primary school students with disabilities: a monograph], Flinta, Moscow; Minin University, Nizhny Novgorod, 2017.

[7] D. V. Zaitsev. Sotsialnaia integratsiia detei-invalidov v sovremennoi Rossii [Social integration of children with disabilities in modern Russia], Nauchnaia kniga, Saratov, 2003.
[8] N. N. Malofeev. Izmenenie spetsialnoi shkoly - neizbezhnyi vsemirnyi protsess [Changes in correctional schools as an unavoidable global process], Nizhegorodskoe obrazovanie, Vol. 3, 4-9, 2010.

[9] E. G. Azina, S. N. Sorokoumova, T. V. Tumanova. Ispolzovanie ritmizatsii $\mathrm{v}$ psikhokorrektsionnom razvitii mladshikh shkolnikov s zaderzhkoi psikhicheskogo razvitiia v usloviiakh inkliuzivnogo obrazovaniia. [The use of rhythmization in the psychocorrectional development of primary school students with mental retardation in inclusive education], Minin University Bulletin, Vol. 7, No. 1, 2019.

[10] I. A. Korobeinikov, I. V. Babkina. Differentsiatsiia obrazovatelnykh potrebnostei kak osnova differentsirovannykh uslovii obrazovaniia detei s zaderzhkoi psikhicheskogo razvitiia [Differentiation of educational needs as the basis of differentiated conditions for the education of children with mental retardation], Defektologia, Vol. 2, 3-13, 2017.

[11] S. A. Rozenblium, T. Iu. Khotyleva, N. V. Borisova. Opisanie modeli inkliuzii, realizuemoi $\mathrm{v}$ sovremennoi obrazovatelnoi situatsii [The description of the model of inclusion implemented in the modern educational situation], Almanac of the Institute of Correctional Pedagogy of the Russian Academy of Education, Vol. 34, 2018.

[12] N. V. Babkina. Psikhologicheskoe soprovozhdenie detei s ZPR v usloviiakh obrazovatelnoi integratsii. [Psychological support for children with mental retardation in the conditions of educational integration], Vospitanie i obuchenie detei s narusheniiami razvitiia, Vol. 1, 23-31, 2012.

[13] N. V. Babkina. Inkliuzivnoe obrazovanie detei s zaderzhkoi psikhicheskogo razvitiia: predposylki i usloviia realizatsii [Inclusive education for children with mental retardation: prerequisites and conditions for implementation], Almanac of the Institute of Correctional Pedagogy of the Russian Academy of Education, Vol. 34, 2018.

[14] Education at a Glance. OECD Indicators, OECD Publishing, Paris. Online available from https://www.oecd-ilibrary.org/ docserver/eag-2016-en.pdf?expires=1582047690\&id=id\&a ccname=guest\&checksum=7869CCF0ADCC6C6CF5390 A18A1572DFC

[15] E. E. Dmitrieva, S. N. Kashtanova, E. Y. Medvedeva, E. A. Olkhina, V. A. Kudryavtsev. Tolerant consciousness of educational and multicultural space subjects, Espacios, Vol. 39, No. 38, 9, 2018.

[16] J. Knight. Updated definition of internationalization. In International Higher Education. The Boston College Center for International High Education, USA, No. 33 Fall, 2003, 2-3. Online available from http://www.bc.edu/content/dam /files/research_sites/cihe/pdf/IHEpdfs/ ihe33.pdf

[17] G. Pelletier. Accompagner les réformes et les innovations en éducation: Consultance, recherches et formation, Editions L'Harmattan, Paris, 2004.

[18] U. V. Ulenkova. Integratsiia detei s zaderzhkoi psikhicheskogo razvitiia v obshcheobrazovatelnuiu sredu: problemy i perspektivy [Integrating children with mental retardation into the general educational environment: problems and perspectives], Special Psychology, Vol. 2, No. 20, 7-10, 2019. 
[19] Federal State Educational Standard for Preschool Education: Pedagogical Education Centre, 2014.

[20] M. Bonami, M. Garant. Systèmes scolaires et pilotage de l'innovation, De Boeck, Bruxelles, 1996.

[21] M. J. Certon. Schools of the Future: How American Business and Education can Cooperate to Serve our Schools, McCrow-Hiïl Book Company, New York, 1985.

[22] L. S. Vygotsky. Osnovy defektologii [The basics of defectology], Pedagogika, Moscow, 1983.

[23] T. V. Ermolova, Sotsialnoe «Ia» kak lichnostnoe novoobrazovanie krizisa 7 let [The social "Me" as a new personality formation of the crisis of 7 years], Teoreticheskaia i eksperimentalnaia psihologiia, Vol. 2, No. 2, 62-71, 2009. 